\title{
Sports injuries in soccer according to tactical position: a retrospective survey
}

\section{Lesões desportivas no futebol segundo posicionamento tático de jogo: análise por inquérito retrospectivo}

\author{
Giuliano Moreto Onaka ${ }^{[a]}$, Jair José Gaspar-Jr ${ }^{[a]}$, Dayana das Graças ${ }^{[a]}$, \\ Fernando Sérgio Silva Barbosa ${ }^{[a, b]}$, Paula Felippe Martinez $^{[a]}$, Silvio Assis de Oliveira-Junior ${ }^{[a]}{ }^{*}$ \\ [a] Universidade Federal de Mato Grosso do Sul (UFMS), Campo Grande, MS, Brazil \\ [b] Universidade Federal da Rondônia (UNIR), Ariquemes, RO, Brazil
}

\begin{abstract}
Introduction: In soccer, the players' positions have been associated with specific functional overload, which may cause sports injuries. Objective: To investigate the occurrence and characterize sport injuries according to soccer player position. Methods: 232 male soccer players (129 professionals and 103 amateurs) from different sport teams in Mato Grosso do Sul, Brazil, were distributed in groups according to their soccer player position. Besides anthropometric characteristics, sports injuries were registered by using a referred morbidity survey. The occurrence of injuries was analyzed by means of the Goodman Test. Logistic regression models were used to investigate the relationship between different risk factors and the occurrence/-recurrence of sports injuries. Results: Forwards showed higher occurrence rates of sport injuries than other soccer position groups. Joint injuries in lower limbs constituted the most frequent registered cases. Muscle injuries in the back region were the most registered sports injuries among midfielders, while muscle damages in lower limbs were the primary
\end{abstract}

\footnotetext{
* GMO: MS, e-mail: gmonaka@hotmail.com JJGJ: BS, e-mail: junior_fisio89@hotmail.com DG: MS, email: dayana.dg.fisio@gmail.com FSSB: MS, e-mail: fernandossb@outlook.br PFM: PhD, email: paulafmartinez@yahoo.com.br SAOJ: PhD, e-mail: oliveirajr.ufms@gmail.com
} 
injuries registered for other line positions. In the etiologic context, contact was the main cause of sports injuries in all groups. Most athletes (195) reported recurrence of sports injuries. Conclusion: The occurrence of sports injuries was higher among forwards. Traumatic joint and muscle injuries were the most prevalent registers in all line positions.

Keywords: Epidemiology. Risk Factors. Sport. Physical Therapy.

\section{Resumo}

Introdução: No futebol, o posicionamento tático de jogo está relacionado com atribuições funcionais específicas, que podem predispor à ocorrência de lesões desportivas. Objetivo: Analisar a ocorrência e caracterizar as lesões desportivas típicas do futebol, relacionando-as com a posição tática de jogo. Métodos: 232 jogadores de futebol do sexo masculino, sendo 129 profissionais e 103 amadores das categorias de base de diferentes equipes desportivas do Mato Grosso do Sul, foram distribuídos em grupos, conforme o posicionamento tático de jogo. Além da caracterização antropométrica, foram tomadas informações sobre lesões desportivas por meio de inquérito de morbidade referida. A ocorrência de lesões foi analisada por meio de teste de Goodman. Modelos de regressão logística foram utilizados para investigar a relação entre diferentes fatores de risco, ocorrência e recidiva de lesão. Resultados: O grupo de Atacantes mostrou as maiores taxas de ocorrência de lesões. Lesões de joelho e tornozelo/pé consistiram nos principais registros articulares entre jogadores de linha, enquanto que afecções de punho e mão foram as mais comuns entre goleiros. As ocorrências musculares de localização lombar foram as mais reportadas por Meias, enquanto as afecções em membros inferiores foram as mais relatadas por laterais, zagueiros, volantes e atacantes. Quanto ao mecanismo etiológico, circunstâncias de trauma prevaleceram em todos os grupos. A maioria dos atletas (195) apresentou recidivas de lesões. Conclusão: A ocorrência de lesões desportivas foi maior entre atacantes. As lesões articulares traumáticas e musculares constituíram-se como os registros mais predominantes em todas as posições de linha.

Palavras-chave: Epidemiologia. Fator de Risco. Esporte. Fisioterapia.

\section{Introduction}

Soccer practice has required the development of different physical characteristics, such as endurance, speed, agility, flexibility, and muscle strength [1 - 3]. Moreover, specific movements of soccer have been commonly associated with traumatic circumstances, running, jumps, intermittent acceleration, as well as speed chances of direction [1 - 5]. In this context, authors have described many specific functional demands common to the diverse soccer player positions [3, 6, 7].

These diverse requests have been associated with anthropometric changes among different soccer player positions; forwards have shown lower body weight and adiposity when compared to goalkeepers and quarterbacks $[8,9]$. Relationships between soccer player position and sports injuries are inconsistent and unclarified though. Although
Hawkins and Fuller [10] had verified that soccer position did not affect the onset of sports injuries, Morgan and Oberlander [11] documented greater prevalence of injuries in midfields of a soccer team. Other authors [12] confirmed that forwards are the most frequently injured players among all soccer athletes. With respect to the characteristics of sports injuries, although many studies have revealed that lower limbs are the main anatomical locations for the onset of sports injuries, there are divergences in relation to their type. While authors [13 - 20] have documented that muscle damages are the most frequent musculoskeletal injuries, other studies have shown that joint and tendon injuries are the main medical registers in soccer [21 - 23].

Therefore, the characteristics of sports current study was injuries according to proposed to analyze soccer player positions. the prevalence and As an initial hypothesis, 
due to the increased number of risk factors, midfielders present higher prevalence of sports injuries than other positions [11]. Also, traumarelated muscle injuries in the lower limbs constitute the most common sports injuries mentioned by soccer players.

\section{Methods}

Study and participants

This is a descriptive and observational study, with retrospective design. Volunteers constituted a convenience sample of 232 male soccer players, recruited from different soccer teams in Mato Grosso do Sul, Brazil. All participants were at least 12 years old, and presented at least 12 months of regular soccer practice in terms of competitive performance. All participants signed a consent document after receiving verbal and written explanations about the procedures and the experimental protocol, as approved by the Research Ethics Committee of the Federal University of Mato Grosso do Sul (CEP/UFMS), register 1.006.805, CAAE 34019614.8.0000.0021.

\section{Study design and field procedures}

With respect to the study design, the volunteers were divided into six groups, based on soccer player positions: Goalkeepers (G1; $\mathrm{n}=21$ ), Quarterbacks (G2; $\mathrm{n}=36$ ), Wingers (G3; $\mathrm{n}=45$ ), Defender Midfielders (G4; $\mathrm{n}=38$ ), Advanced Midfielders (G5; $n=50$ ), and Forwards (G6; $\mathrm{n}=42$ ). All participants were interviewed once in order to register information on their general and epidemiological characteristics. Height was measured using a metal tape adjusted on a wall [24]. Body mass assessment was performed using digital scales (Omron ${ }^{\circledR}$, Kyoto, Japan).

In order to obtain retrospective information on retrospective sports injuries, a reported condition inquiry was adopted, according to previous studies $[14,25,26]$. Data were collected individually through interviews by a single examiner who was familiar with the instrument. The inquiry addressed personal data, such as age, weight, height, and duration of training in years. Sports injuries were characterized in terms of type, anatomical site affected, etiological mechanism of the injury, when the injury occurred, severity of the injury, requests for medical support, morbidity, return to normal activities, and recurrences [26]. Also, sports injury in the present study was defined as any physical complaint resulting from training and/or competition that limited the participation of the individual for at least one day, regardless of the need for medical care [27]. The severity of the injury was classified based on the time the athlete spends away from the sport for recovery: mild injury ( 1 to 7 days away from sport), moderate injury (8 to 28 days away from sport) or severe injury (more than 28 days away from sport or permanent injury) [27].

\section{Statistical analysis}

Results of age and anthropometrical characteristics were analyzed using analysis of variance (ANOVA), and Dunn's test for nonparametric measures. Parametric distributions of duration of training and weekly duration of training were analyzed by ANOVA and Student-NewmanKeuls test. In order to evaluate the proportional distribution and characteristics of sports injuries according to soccer player positions, Goodman's test for contrasts within and between multinomial populations was used. Statistical significance was set at $5 \%$ for all conclusions.

\section{Results}

General characteristics as well as information about sports injuries are displayed in Table 1. Groups were different with respect to anthropometrical variables $(p<0.05)$; generally, wingers and advanced midfielders showed lower measures of height and body mass. In the epidemiological context, forwards presented increased incidence of sports injuries (Table 1). 
Table 1 - Demographic and anthropometric results, and epidemiology of sports injuries according to soccer player position

\begin{tabular}{lcccccc}
\hline & \multicolumn{9}{c}{ Group } \\
\cline { 2 - 7 } \multicolumn{1}{c}{ Results } & $\mathbf{G 1}$ & $\mathbf{G 2}$ & $\mathbf{G 3}$ & $\mathbf{G 4}$ & $\mathbf{G 5}$ & $\mathbf{G 6}$ \\
& $\mathbf{n = 2 1}$ & $\mathbf{n}=\mathbf{3 6}$ & $\mathbf{n}=\mathbf{4 5}$ & $\mathbf{n}=\mathbf{3 8}$ & $\mathbf{n = 5 0}$ & $\mathbf{n}=\mathbf{4 2}$ \\
\hline Age (Years) & $20.0 \pm 10.3$ & $20.0 \pm 8.0$ & $16.0 \pm 7.3$ & $22.0 \pm 12.0$ & $17.5 \pm 9.0$ & $19.0 \pm 9.0$ \\
Height (cm) & $183.0 \pm 8.5$ & $184.0 \pm 9.7$ & $172.0 \pm 9.0^{*} \#$ & $176.8 \pm 9.0^{\dagger}$ & $171.5 \pm 10.2^{* \# \dagger}$ & $176.0 \pm 12.0^{\#}$ \\
B. M. (kg) & $82.9 \pm 13.6$ & $79.2 \pm 19.4$ & $65.6 \pm 17.6^{*}$ & $76.5 \pm 15.0^{\dagger}$ & $63.6 \pm 17.2^{*} \$$ & $67.8 \pm 17.9^{*}$ \\
T. (months) & $116 \pm 64$ & $106 \pm 59$ & $89 \pm 64$ & $131 \pm 71$ & $107 \pm 54$ & $118 \pm 65$ \\
WT. (h) & $11.2 \pm 5.4$ & $10.8 \pm 5.5$ & $10.6 \pm 5.3$ & $11.0 \pm 5.4$ & $10.5 \pm 4.7$ & $12.0 \pm 5.7$ \\
SI/Athlete & 3.1 & 3.11 & 2.89 & 3.45 & 3.2 & 3.76 \\
SI/ In.A. & 3.1 & 3.2 & 3.02 & 3.45 & 3.48 & 3.85 \\
SI (cases) & 65 & 112 & 130 & 131 & 160 & 158 \\
\hline
\end{tabular}

Note: G1, goalkeepers; G2, quarterbacks; G3, wingers; G4, defender midfielders; G5, advanced midfielders; G6, forwards; B. M., body mass; T., duration of training practice; WT., duration of weekly training practice; SI/Athlete, incidence of sports injuries per athlete; SI/In.A., incidence of sports injuries per injuried athlete; SI, number of sports injuries. T. and WT. expressed in mean \pm SD; ANOVA and Student-Newman-Keuls test. Anthropometric variables are presented in median \pm interval between 25 th and 75 th percentiles; ${ }^{*} p<0.05$ vs. G1; ${ }^{\#} p<0.05$ vs. G2; ${ }^{\dagger} p<0.05$ vs. G3; $\$ p<0.05$ vs. G4; Kruskal-Wallis ANOVA and Dunn's test.

Descriptive characteristics of sports injuries were displayed in Table 2. The most prevalent registers in all study groups were joint injuries; muscle injuries were another predominant condition among Wingers, Defender Midfielders, Advanced Midfielders, and Forwards. Generally, groups presented a similar distribution of sports injuries. With respect to anatomical sites, an increased prevalence of sports injuries with onset in the lower limbs was found. Goalkeepers showed a higher prevalence of sports injuries on sites from the upper limbs though in comparison to the other anatomical locations. With regard to etiological mechanisms, trauma constituted the main circumstance to induce sports injuries, despite the position. Moreover, all groups showed a higher proportion of recurrent injuries than novel cases.

Table 2 - Absolute and relative (\%) distribution of sports injuries, according to nature, anatomical site, etiological mechanism, and soccer player position

\begin{tabular}{|c|c|c|c|c|c|c|c|}
\hline \multirow{2}{*}{\multicolumn{2}{|c|}{ Variables }} & \multicolumn{6}{|c|}{ Group } \\
\hline & & Gl & G2 & G3 & G4 & G5 & G6 \\
\hline \multirow{6}{*}{ 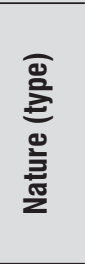 } & Muscle & $14(21.5)^{A b c}$ & $29(25.9)^{A b}$ & $57(43.8)^{A c}$ & $58(44.3)^{A c}$ & $51(31.9)^{\mathrm{Ab}}$ & $49(31.0)^{A c}$ \\
\hline & Joint & $30(46.2)^{A c}$ & $58(51.8)^{A c}$ & $51(39.2){ }^{A c}$ & $53(40.5)^{\mathrm{Ac}}$ & $74(46.3)^{A b}$ & $66(41.8)^{\mathrm{Ac}}$ \\
\hline & Bone & $10(15.4)^{A b}$ & $9(8.0)^{A a}$ & $14(10.8)^{A b}$ & $10(7.6)^{A b}$ & $19(11.9)^{\mathrm{Aa}}$ & $18(11.4)^{A b}$ \\
\hline & Tendon & $5(7.7)^{\text {Aab }}$ & $3(2.7)^{\mathrm{Aa}}$ & $0(0.0)^{\mathrm{Aa}}$ & $5(3.8)^{\mathrm{Aab}}$ & $5(3.1)^{\mathrm{Aa}}$ & $7(4.4)^{\mathrm{Aab}}$ \\
\hline & Tegumentary & $6(9.2)^{\mathrm{Aab}}$ & $10(8.9)^{\mathrm{Aa}}$ & 7 (5.4) Aab & $5(3.8)^{\mathrm{Aab}}$ & $6(3.8)^{\mathrm{Aa}}$ & $15(9.5)^{\mathrm{Aab}}$ \\
\hline & Unspecific & $0(0.0)^{\mathrm{Aa}}$ & $3(2.7)^{\mathrm{Aa}}$ & $1(1.0)^{\mathrm{Aa}}$ & $0(0.0)^{\mathrm{Aa}}$ & $5(3.1)^{\mathrm{Aa}}$ & $3(1.9)^{\mathrm{Aa}}$ \\
\hline \multirow{4}{*}{ 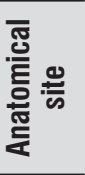 } & Head/neck & 8 (12.3) Aab & $14(12.5)^{\mathrm{Aa}}$ & $10(7.7)^{\mathrm{Aa}}$ & $6(4.6)^{\mathrm{Aa}}$ & $7(4.4)^{\mathrm{Aa}}$ & $17(10.8)^{\mathrm{Aa}}$ \\
\hline & Trunk & $7(10.8)^{\mathrm{Aa}}$ & $8(7.1)^{\mathrm{Aa}}$ & $9(6.9)^{\mathrm{Aa}}$ & $7(5.3)^{\mathrm{Aa}}$ & $13(8.1)^{\mathrm{Aa}}$ & $13(8.2)^{\mathrm{Aa}}$ \\
\hline & Upper limbs & $21(32.3)^{\mathrm{Bbc}}$ & $7(6.3)^{\mathrm{Aa}}$ & $11(8.5)^{\text {Аа }}$ & $9(6.9)^{\mathrm{Aa}}$ & $10(6.3)^{\mathrm{Aa}}$ & $16(10.1)^{\mathrm{Aa}}$ \\
\hline & Lower limbs & $29(44.6)^{A c}$ & $83(74.1)^{\mathrm{Bb}}$ & $100(76.9)^{\mathrm{Bb}}$ & $109(83.2)^{\mathrm{Bb}}$ & $130(81.3)^{\mathrm{Bb}}$ & $112(70.9)^{\mathrm{Bb}}$ \\
\hline \multirow{8}{*}{ 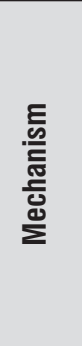 } & Running & $3(4.6)^{\mathrm{Aa}}$ & $9(8.0)^{A a}$ & $25(19.2)^{A b}$ & $26(19.8)^{A c}$ & $19(11.9)^{A b c}$ & $27(17.1)^{\mathrm{Ad}}$ \\
\hline & Jump & $8(12.3)^{\mathrm{Aa}}$ & $8(7.1)^{\mathrm{Aa}}$ & $4(3.1)^{\mathrm{Aa}}$ & $8(6.1)^{A b}$ & $4(2.5)^{\mathrm{Aa}}$ & $11(7.0)^{\text {Abcd }}$ \\
\hline & Tech. mov. & $7(10.8)^{\mathrm{Aa}}$ & $7(6.3)^{\mathrm{Aa}}$ & $24(18.5)^{A b}$ & $17(13.0)^{A b c}$ & $29(18.1)^{A c}$ & $18(11.4)^{\mathrm{Acd}}$ \\
\hline & Trauma & $42(64.6)^{A b}$ & $74(66.1)^{A b}$ & $63(48.5)^{\mathrm{Ac}}$ & $61(46.6)^{\mathrm{Ad}}$ & $81(50.6)^{\mathrm{Ad}}$ & $92(58.2)^{\mathrm{Ae}}$ \\
\hline & Spin & $1(1.5)^{\mathrm{Aa}}$ & $6(5.4)^{\mathrm{Aa}}$ & $5(3.8)^{\mathrm{Aa}}$ & $9(6.9)$ Aabc & $8(5.0)^{A a b}$ & $2(1.3)^{\text {Aab }}$ \\
\hline & Chronic mov. & $2(3.1)^{\mathrm{Aa}}$ & $1(0.9)^{\mathrm{Aa}}$ & $2(1.5)^{\mathrm{Aa}}$ & $4(3.1)^{\mathrm{Aab}}$ & $5(3.1)^{\mathrm{Aab}}$ & $3(1.9)^{\mathrm{Aab}}$ \\
\hline & Phys. T. & $0(0.0)^{\mathrm{Aa}}$ & $5(4.4)^{\mathrm{Aa}}$ & $5(3.8)^{\mathrm{Aa}}$ & $6(4.6)^{\text {Aab }}$ & $11(6.9)^{\text {Aabc }}$ & 5 (3.2) Aabc $^{-1}$ \\
\hline & Other & $2(3.1)^{\mathrm{Aa}}$ & $2(1.8)^{\mathrm{Aa}}$ & $2(1.5)^{\mathrm{Aa}}$ & $0(0.0)^{A a}$ & $3(1.9)^{\mathrm{Aa}}$ & $0(0.0)^{\mathrm{Aa}}$ \\
\hline
\end{tabular}


(Conclusion)

Table 2 - Absolute and relative (\%) distribution of sports injuries, according to nature, anatomical site, etiological mechanism, and soccer player position

\begin{tabular}{|c|c|c|c|c|c|c|c|}
\hline \multirow{2}{*}{\multicolumn{2}{|c|}{ Variables }} & \multicolumn{6}{|c|}{ Group } \\
\hline & & $\begin{array}{c}\text { Gl } \\
n=21\end{array}$ & $\begin{array}{c}\text { G2 } \\
\mathrm{n}=36\end{array}$ & $\begin{array}{c}\text { G3 } \\
n=45\end{array}$ & $\begin{array}{c}\text { G4 } \\
\mathrm{n}=38\end{array}$ & $\begin{array}{c}\text { G5 } \\
\mathrm{n}=50\end{array}$ & $\begin{array}{c}\text { G6 } \\
n=42\end{array}$ \\
\hline \multirow{2}{*}{ 咅 } & No (absence) & $21(32.3)^{\mathrm{Aa}}$ & $35(31.3)^{\mathrm{Aa}}$ & $43(35.8)^{\mathrm{Aa}}$ & $38(29.0)^{\mathrm{Aa}}$ & $46(28.8)^{\mathrm{Aa}}$ & $41(25.9)^{\mathrm{Aa}}$ \\
\hline & Yes (presence) & $44(67.7)^{\mathrm{Ab}}$ & $77(68.8)^{\mathrm{Ab}}$ & $77(64.2)^{\mathrm{Ab}}$ & $93(71.0)^{\mathrm{Ab}}$ & $114(71.2)^{\mathrm{Ab}}$ & $117(74.1)^{\mathrm{Ab}}$ \\
\hline
\end{tabular}

Note: G1, goalkeepers; G2, quarterbacks; G3, wingers; G4, defender midfielders; G5, advanced midfielders; G6, forwards; Tech. mov., technical movement; Chronic mov., chronic/ repetitive movement; Phys. T., physical training activities; Recur., recurrent injury; A, B $p<0.05$ for horizontal comparisons (among groups); a, b $p<0.05$ for vertical comparisons (within group); Goodman's test for contrasts among and within multinomial populations.

Based on the most frequent cases in relation to nature and anatomical site, the proportions of joint and muscle injuries according to anatomical site and soccer player position are presented in Table 3. Regarding joint sites, injuries in the knee and ankle/ foot complex were the most common occurrences reported by line soccer players. Differently, joint injuries in handles and hands were more mentioned by goalkeepers, while ankle sprains were more frequently registered among forwards.

With respect to muscle cases, while advanced midfielders referred back injuries as the most common occurrences, hamstring strains were the most reported injuries by wingers and forwards. On the other hand, muscle injuries in groin and hip sites were the most important events mentioned by quarterbacks and defender midfielders (Table 3).

Table 3 - Absolute and relative (\%) distribution of joint and muscle injuries according to anatomical site and soccer player position

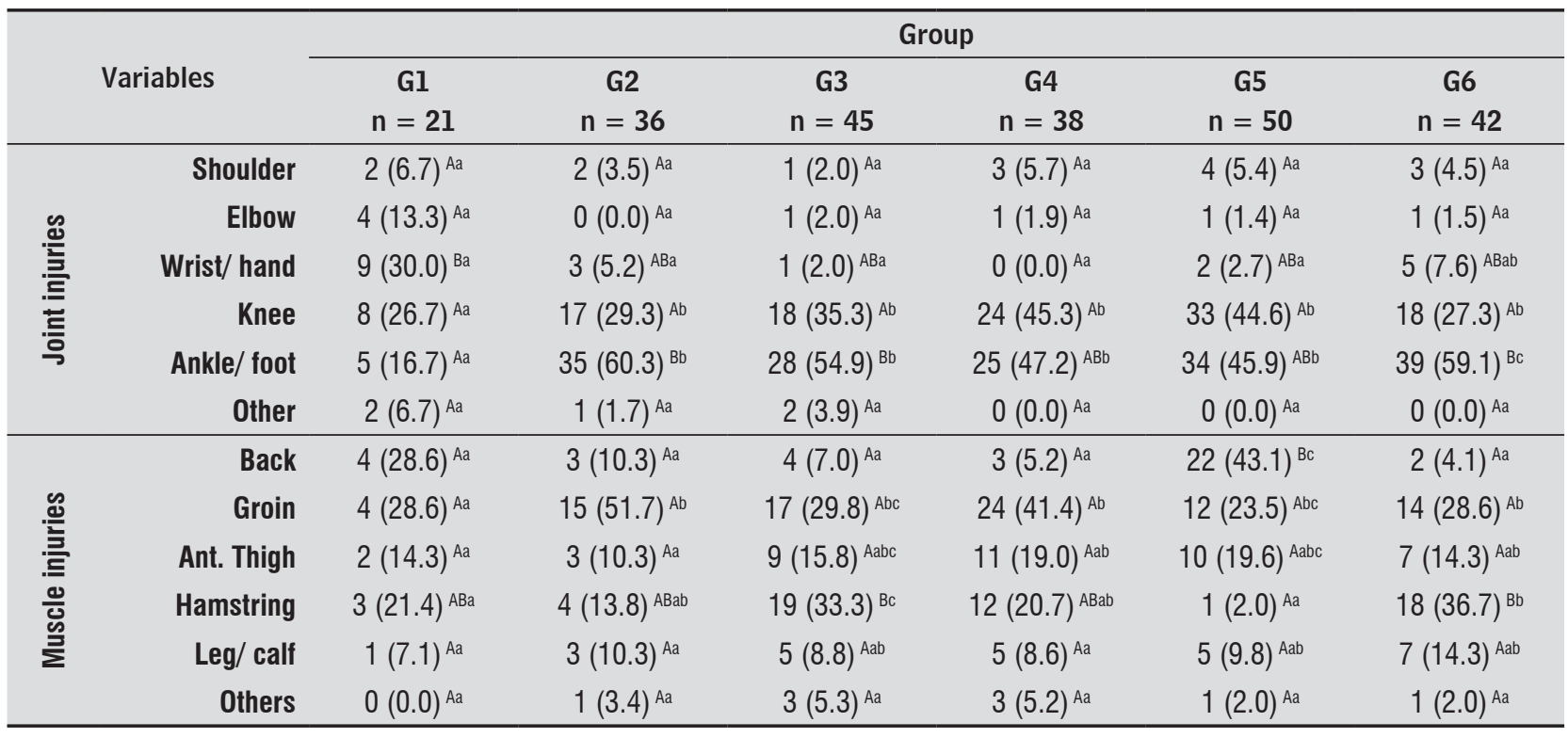

Note: G1, goalkeepers; G2, quarterbacks; G3, wingers; G4, defender midfielders; G5, advanced midfielders; G6, forwards; Ant. Thigh, anterior site of thighs; $\mathrm{A}, \mathrm{B} p<0.05$ for horizontal comparisons (among groups); ${ }_{a, b} \mathrm{p}<0.05$ for vertical comparisons (within group); Goodman's test for contrasts among and within multinomial populations.

Importantly, most groups showed greater prevalence of severe sports injuries than mild and moderate registers. There was increased proportion of sports injuries without removal among goalkeepers though $(\mathrm{n}=22 ; 34.9 \%$, $\mathrm{p}<0.05$; Figure 1). 


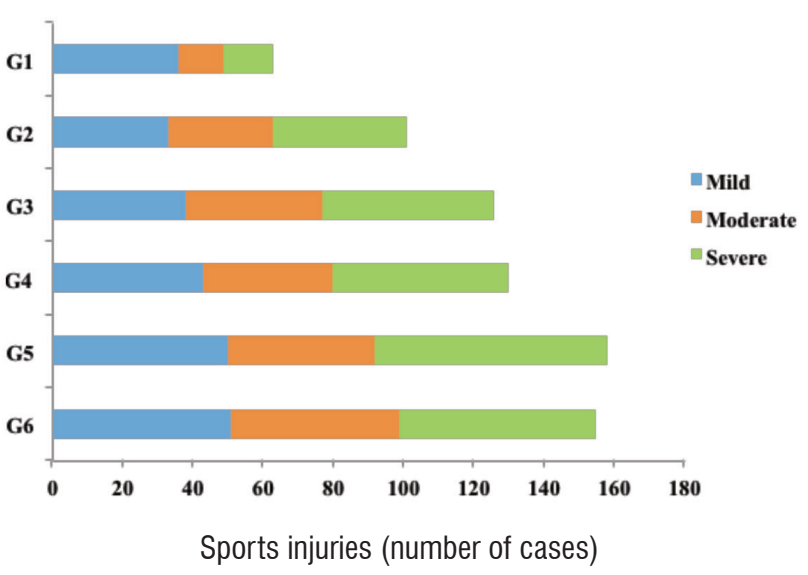

Figure $\mathbf{1}$ - Sports injury distribution according to severity and soccer player position.

Note: G1, goalkeepers; G2, quarterbacks; G3, wingers; G4, defender midfielders; G5, advanced midfielders; G6, forwards.

A greater proportion of sports injuries resulted in requests for medical support. Advanced midfielders reported a large proportion of symptoms during functional return, although most cases had received medical and therapeutic interventions.

Table 4 - Absolute and relative (\%) distribution of sports injuries according to requirement of medical treatment, presence of symptoms during functional return, and soccer player position

\begin{tabular}{ccccc}
\hline \multirow{2}{*}{ Groups } & Medical & \multicolumn{2}{c}{ Return } & \multirow{2}{*}{ intervention } \\
\cline { 3 - 4 } & Asymptomatic & Symptomatic & \\
\hline G1 & No (Absence) & $8(36.4)^{\text {Aa }}$ & $14(63.6)^{\text {Aa }}$ & $\mathbf{2 2}$ \\
$(\mathrm{n}=21)$ & Yes (Presence) & $19(45.2)^{\text {Aa }}$ & $23(54.8)^{\text {Aa }}$ & $\mathbf{4 2}$ \\
G2 & No (Absence) & $18(51.4)^{\text {Aa }}$ & $17(48.6)^{\text {Aa }}$ & $\mathbf{3 5}$ \\
$(\mathrm{n}=36)$ & Yes (Presence) & $44(57.1)^{\text {Aa }}$ & $33(42.9)^{\text {Aa }}$ & $\mathbf{7 7}$ \\
G3 & No (Absence) & $12(37.5)^{\text {Aa }}$ & $20(62.5)^{\text {Aa }}$ & $\mathbf{3 2}$ \\
$(\mathrm{n}=45)$ & Yes (Presence) & $53(57.0)^{\text {Aa }}$ & $40(43.0)^{\text {Aa }}$ & $\mathbf{9 3}$ \\
G4 & No (Absence) & $12(36.4)^{\text {Aa }}$ & $21(63.6)^{\text {Ab }}$ & $\mathbf{3 3}$ \\
$(\mathrm{n}=38)$ & Yes (Presence) & $57(58.8)^{\text {Ab }}$ & $40(41.2)^{\text {Aa }}$ & $\mathbf{9 7}$ \\
G5 & No (Absence) & $35(61.4)^{\text {Ab }}$ & $22(38.6)^{\text {Aa }}$ & $\mathbf{5 7}$ \\
$(\mathrm{n}=50)$ & Yes (Presence) & $39(38.6)^{\text {Aa }}$ & $62(61.4)^{\text {Bb }}$ & $\mathbf{1 0 1}$ \\
G6 & No (Absence) & $23(65.7)^{\text {Ab }}$ & $12(34.3)^{\text {Aa }}$ & $\mathbf{3 5}$ \\
$(n=45)$ & Yes (Presence) & $51(42.5)^{\text {Aa }}$ & $69(57.5)^{\text {Ab }}$ & $\mathbf{1 2 0}$ \\
\hline
\end{tabular}

Note: G1, goalkeepers; G2, quarterbacks; G3, wingers; G4, defender midfielders; G5, advanced midfielders; G6, forwards; $A, B p<0.05$ for horizontal comparisons (among groups); a,b $p<0.05$ for vertical comparisons (within group); Goodman's test for contrasts among and within multinomial populations.

\section{Discussion}

The current study was proposed to analyze the prevalence and to characterize typical soccer sports injuries, according to soccer player position. As opposed to the initial hypothesis, forwards showed a higher prevalence of sports injuries than other soccer player positions. Injuries in knees and ankle/ foot sites were the most reported joint injuries by line soccer players, while wrist and hand injuries were most common among goalkeepers. Also, muscle injuries in back sites were more reported by advanced midfielders, while hamstring cases were more prevalent in wingers and forwards, and groin injuries were the more common occurrences in quarterbacks and defender midfielders.

In the epidemiological context, greater prevalence of sports injuries in forwards was in accordance with previous findings [12, 23]; some studies documented that other soccer positions were associated with greater predominance of injuries though [11, 28], while additional authors verified comparable prevalence among all soccer positions [10, 29]. Likewise, increased onset of sports injuries in lower limbs related by line soccer players has been sustained in other investigations $[14,22,28]$. Classically, upper limb injuries are unusual among soccer players; when present, these registers have been associated to brief morbidity and removal [30]. In response to functional specialty, upper limb affections are more common in goalkeepers, as supported by our results. Actually, frequent hand use during a soccer match, besides traumatic demands due to interceptions and soccer game disputes have contributed to high prevalence of joint injuries on wrist/ hand sites, as verified in the goalkeepers group (Table 3 ).

In this perspective, modern soccer training has been characterized by requirements concerning multiple athletic capacities, including demands for strength, speed, endurance, and motor control $[31,32]$. In combination with high competitive demand, these conditions contribute to a high frequency of physical contact, and have been associated to repetitive running, jumps, and speed changes in terms of continuous displacements. Consequently, these circumstances might be associated, respectively, to a greater proportion of traumatic joint injuries in knee and ankle sites [14, 23, 28], besides ruptures of hamstring and groin muscles in wingers 
and forwards (Table 3). These results are also related with functional specialties, characterized by important muscle requirements in terms of explosion and potency [31,33]. Irregular grounds as well as lesser physical characteristics against opponents [8,9] could also induce joint trauma in wingers and forwards.

Likewise, extrinsic and specific demands common to soccer games might result in ankle strains and rupture of groin muscles, as presented by quarterbacks and defend midfielders. Although diverse, requirements of these positions include interceptions during matches' dynamic circumstances, characterized by numerical handicaps and demands for defense actions in order to recover the ball [33]. Hence, important contractile demands on hip muscles have been associated with frequent muscle retraction among soccer players [21,34], contributing to excessive back lordosis and hip misalignment [35]. Accentuated prevalence of muscle injuries in back sites in advanced midfielders (Table 3) can derive from repetitive functional overload and hip muscle retractions.

Moreover, advanced midfielders showed greater symptomatic manifestations during sport return, while an increased proportion of sports injuries was associated with medical intervention and high severity (Figure 1). Severe injuries result in significant morbidity and increased probability of incomplete recovery [36]. Amplified morbidity of sports injuries and high proportion of muscle injuries in back sites in advanced midfielders might be sustained by the absence of a permanent medical department with specialized professionals. As a result, prevention and treatment programs directed to sports injuries in soccer players from Mato Grosso do Sul, Brazil, are insufficient and inadequate, promoting prolonged recovery and longer functional removal. Importantly, no soccer team has been maintaining medical and therapeutic support services in order to treat and recover eventual sports injuries; these characteristics probably contributed to an increased proportion of recurrent sports injuries in all groups (Table 2).

The objective of the present study was attained, as it offers an epidemiological approach of sports injuries associated to tactical soccer positions. In this context, using a survey questionnaire is adequate and has contributed to document various types of information on multiple sports modalities [14, 22, 26, 27]. Other studies are needed to analyze the pathophysiology and prevalence of sports injuries in soccer players, including investigations with respect to risk factors responsible for the onset of novel injuries.

\section{Conclusions}

The prevalence of sports injuries was higher in forwards than other soccer player positions. Injuries in knee and ankle sites were the most frequent joint injuries in line soccer players, while sports affections in wrists and hands were more reported by goalkeepers. Muscle injuries in back sites were the main occurrences mentioned by advanced midfielders, while lower-limb muscle injuries were more common among quarterbacks, wingers, defend midfielders and forwards.

\section{References}

1. Hoff J. Training and testing physical capacities for elite soccer players. J Sports Sci. 2005;23(6):573-82.

2. Kettunen JA, Kujala UM, Kaprio J, Koskenvuo M, Sarna S. Lower-limb function among former elite male athletes. Am J Sports Med. 2001;29(1):2-8.

3. Di Salvo V, Baron R, Tschan H, Calderon Montero FJ, Bachl N, Pigozzi F. Performance characteristics according to playing position in elite soccer. Int J Sports Med. 2007;28(3):222-7.

4. Arnason A, Sigurdsson SB, Gudmundsson A, Holme I, Engebretsen L, Bahr R. Risk factors for injuries in football. Am J Sports Med. 2004;32(1 Suppl):5S-16s.

5. Krist MR, van Beijsterveldt AMC, Backx FJG, de Wit GA. Preventive exercises reduced injury-related costs among adult male amateur soccer players: a clusterrandomised trial. J Physiother. 2013;59(1):15-23.

6. Coelho DB, Mortimer LA, Condessa LA, Morandi RF, Oliveira BM, Marins JCB, et al. Intensity of real competitive soccer matches and differences among player positions. Rev Bras Cineantropom Desempenho Hum. 2011;13(5):341-7.

7. Bastos FN, Vanderlei FM, Vanderlei LCM, Netto Jr J, Pastre CM. Investigation of characteristics and risk factors of sports injuries in young soccer players: a retrospective study. Int Arch Med. 2013;6(1):14. 
8. Reilly T, Bangsbo J, Franks A. Anthropometric and physiological predispositions for elite soccer. J Sports Sci. 2000;18(9):669-83.

9. Noh JW, Kim MY, Lee LK, Park BS, Yang SM, Jeon HJ, et al. Somatotype and body composition analysis of Korean youth soccer players according to playing position for sports physiotherapy research. J Phys Ther Sci. 2015;27(4):1013-7.

10. Hawkins RD, Fuller CW. An examination of the frequency and severity of injuries and incidents at three levels of professional football. Br J Sports Med. 1998;32(4):326-32.

11. Morgan BE, Oberlander MA. An examination of injuries in major league soccer. The inaugural season. Am J Sports Med. 2001;29(4):426-30.

12. Carling C, Orhant E, LeGall F. Match injuries in professional soccer: inter-seasonal variation and effects of competition type, match congestion and positional role injury in professional soccer. Int J Sports Med. 2010;31(4):271-6.

13. Pedrinelli A, Cunha Filho GAR, Thiele ES, Kullak OP. Estudo epidemiológico das lesões no futebol profissional durante a Copa América de 2011, Argentina. Rev Bras Ortop. 2013;48(2):131-6.

14. Silveira KP, Assunção VHS, Guimarães Jr NP, Barbosa SRM, Santos MLM, Christofoletti G, et al. Nosographic profile of soccer injuries according to the age group. Rev Bras Cineantropom Desempenho Hum. 2013;15(4):476-85.

15. Zanuto EAC, Harada H, Gabriel Filho LRA. Análise epidemiológica de lesões e perfil físico de atletas do futebol amador na região do oeste paulista. Rev Bras Med Esporte. 2010;16(2):116-20.

16. Zavarize SF, Souza DL, Granghelli M, Rosalino R, Voltan MZ, Martelli A. Incidência de lesões musculoesqueléticas nas equipes base de futebol da Associação Atlética Ponte Preta. Saúde Desenvolv Hum. 2013;1(2):37-46.

17. Selistre LFA, Taube OLS, Ferreira LMA, Barros Jr EA. Incidência de lesões nos jogadores de futebol masculino sub-21 durante os Jogos Regionais de Sertãozinho-SP de 2006. Rev Bras Med Esporte. 2009;15(5):351-4.
18. 18. Waldén M, Hägglund M, Ekstrand J. Injuries in Swedish elite football: a prospective study on injury definitions, risk for injury and injury pattern during 2001. Scand J Med Sci Sports. $2005 ; 15(2): 118-25$.

19. Agel J, Evans TA, Dick R, Putukian M, Marshall SW. Descriptive epidemiology of collegiate men's soccer injuries: national collegiate athletic association injury surveillance system, 1988-1989 through 20022003. J Athl Train. 2007;42(2):270-7.

20. Brito J, Malina RM, Seabra A, Massada JL, Soares JM, Krustrup P, et al. Injuries in Portuguese youth soccer players during training and match play. J Athl Train. 2012;47(2):191-7.

21. Kleinpaul JF, Mann L, Santos SG. Lesões e desvios posturais na prática de futebol em jogadores jovens. Fisioter Pesqui. 2010;17(3):236-41.

22. Santos GP, Assunção VHS, Martinez PF, Christofoletti G, Oliveira-Junior SA. Incidência de lesões desportivas e supratreinamento no futebol. ConScientiae Saúde. 2014;13(2):203-210.

23. Fachina RJFG, Andrade MS, Silva FR, WaszczukJunior S, Montagner PC, Borin JP, et al. Descriptive epidemiology of injuries in a Brazilian premier league soccer team. Open Access J Sports Med. 2013;4:171-4.

24. Leite N, Aguiar Jr RP, Cieslak F, Ishiyama M, Milano GE, Stefanello JMF. Perfil da aptidão física dos praticantes de Le Parkour. Rev Bras Med Esporte. 2011;17(3):198-201.

25. Pereira MG. Epidemiologia teoria e prática. 1st ed. Rio de Janeiro: Guanabara Koogan; 1995.

26. Pastre CM, Carvalho Filho G, Monteiro HL, Netto Jr J, Padovani CR. Lesões desportivas no atletismo: comparação entre informações obtidas em prontuários e inquéritos de morbidade referida. Rev Bras Med Esporte. 2004;10(1):1-8.

27. Fuller CW, Ekstrand J, Junge A, Andersen TE, Bahr $\mathrm{R}$, Dvorak J, et al. Consensus statement on injury definitions and data collection procedures in studies of football (soccer) injuries. Clin J Sport Med. 2006;16(2):97-106. 
28. Reis GF, Santos TRT, Lasmar RCP, Oliveira Jr O, Lopes RFF, Fonseca ST. Sports injuries profile of a first division Brazilian soccer team: a descriptive cohort study. Braz J Phys Ther. 2015:19(5):390-7.

29. Dauty M, Collon S. Incidence of injuries in French professional soccer players. Int J Sports Med. 2011;32(12):965-9.

30. Manning MR, Levy RS. Soccer. Phys Med Rehabil Clin N Am. 2006;17(3):677-95.

31. Fonseca ST, Souza TR, Ocarino JM, Gonçalves GP, Bittencourt NF. Applied biomechanics of soccer. In: Magee DJ, Manske RC, Zachazewski JE, Quillen WS, editors. Athletic and sport issues in musculoskeletal rehabilitation. 1st ed. St. Louis: Elsevier Saunders; 2011. p. 287-306.

32. Bahr R, Holme I. Risk factors for sports injuries - a methodological approach. Br J Sports Med. 2003;37(5):384-92.
33. Gomes AC, Souza J. Futebol: treinamento desportivo de alto rendimento. $1^{\text {a }}$ ed. Porto Alegre: Artmed; 2008.

34. Sena DA, Ferreira FM, Melo RHG, Taciro C, Carregaro RL, Oliveira Jr SA. Análise da flexibilidade segmentar e prevalência de lesões no futebol segundo faixa etária. Fisioter Pesqui. 2013;20(4):343-8.

35. Higashihara A, Nagano Y, Takahashi K, Fukubayashi T. Effects of forward trunk lean on hamstring muscle kinematics during sprinting. J Sports Sci. 2015;33(13):1366-75.

36. Wong $\mathrm{P}$, Hong Y. Soccer injury in the lower extremities. Br J Sports Med. 2005;39(8): 473-82.

Received in 06/22/2016

Recebido em 22/06/2016

Approved in 09/18/2017

Aprovado em 18/09/2017 